УДК 811.11

DOI: 10.33184/YVDK-2021-04-30.54

Р.К. Нафикова (асn. БашГУ, г. Уфа)

\title{
«МЕДВЕДЬ» В ТОПОНИМИЧЕСКОЙ СИСТЕМЕ США
}

В данной статье рассматривается особенности номинации географических объектов в США с зооэлементом «bеаг». Топонимы с зоонимными компонентами занимают важное место среди северо-американских географических названий, что объясняется давней связью человека и животных. Проводится количественный анализ данных зоотопонимов $в$ каждом штате, выделяются наиболее частотные топонимы с данным зоокомпонентом. Подтверждается связь между сознанием человека и языком. Делается вывод о том, как объекты окружающей среды влияют на сознание человека и его язык, а также на процесс номинации географических объектов.

Ключевые слова: познание, топоним, зоонимические единиць, зоотопоним, номинация, вторичная номинация, гидроним, ороним, спелеоним.

Каждый язык является основным инструментом хранения и получения информации об окружающем мире, а языковая система сама по себе содержит в себе определенное видение мира, дает представление о его сущностях и явлениях [Болдырев 2016: 18].

Язык является одним из основных средств познавательного процесса. Данное свойство языка существенно значимо для понимания устройства и работы человеческого сознания, если опираться на современные исследования языка с когнитивных позиций. В одном случае, такое свойство языка, как структурированность, является доказательством того, что она присуща и сознанию. В другом случае, можно утверждать, что значительна роль самого языка в процессах структурирования как обыденного, так и научного сознания [Болдырев 2016: 21]. Таким образом, по мнению Б.А. Серебренникова, язык объясняет содержание концептуальной картины мира и активно участвует в формировании ее структуры [Серебренников 1988: 95]. 
Психологи и философы дают определение человеческому сознанию как высшей форме отражения реальности, характерной только человеку. Отмечается, что сознание является единством психических процессов, которые динамично принимают участие в осмыслении человеком не только объективного мира, но и своего собственного бытия. Сознание возникает в процессе жизнедеятельности людей, и оно неразрывно связано с языком. Поскольку сознание сопровождает и контролирует взаимодействие человека с окружающей средой, оно находится между воздействующим извне раздражением и соответствующей этому раздражению реакцией [Болдырев 2019: 526].

Процесс номинации географических объектов вызывает интерес тем, что является когнитивным процессом, где мышление человека отражается в языке. В данной статье рассматриваются зоонимические единицы в географических названиях. Зоонимическая лексика занимает заметное место в системе названий географических объектов. Зоотопонимы вызывают широкий интерес не только лингвистов, но и географов, зоологов.

Топонимы представляют собой обширный пласт лексики английского языка США. Топонимы тесно связаны также с обитателями природы североамериканского континента: растений и животного мира. Географические названия с зоонимными компонентами - достаточно распространенное явление среди американских топономинаций, что объясняется древней связью человека и животных.

В данном исследовании анализируются топонимы США с зоокомпонентом bear - «медведь». Материалом послужили примеры географических объектов, выбранные из электронной системы GNIS. Цель работы - сравнить ареал обитания данного животного с количеством топонимов с зоонимическим элементом «медведь» в каждом штате. Полученные результаты помогают выявить зависимость процесса номинации географических объектов от окружающей среды, в которой обитает человек.

Американский черный медведь - наиболее распространенный вид медведей в Северной Америке, и у него самый большой ареал обитания. В Соединенных Штатах черные медведи распространены на юго-востоке страны. В штате Флорида, где насчитывается 132 зоотопонима с элементом bear, Южная и Северная Каролина - 214 наименований, Луизиана - 67 
наименований. $\mathrm{B}$ этих штатах зоотопонимы встречаются преимущественно в названиях гидронимов, а именно болот, ручьев, озер: Bear Bay, Bear Branch, Bear Creek, Bear Cut, Bear Lake и т.д. Распространены черные медведи также вдоль западного побережья, в Скалистых горах. Так, в Аризоне насчитывается 239 зоотопонимов с элементом bear, в Колорадо 292 ед., в Айдахо - 274 ед., в Монтане - 315 ед., в Неваде - 15 ед., в Нью-Мексико - 183 ед., в Юте - 175 и в Вайоминге - 188 ед. Наименования с данным зоокомпонентом распространены в названиях долин и равнин (Bear Canyon, Bear Flat, Bear Gulch), гор, скал и вершин (Bear Mountain, Bear Headland, Bear Draw, Bear Peak), и гидронимов (Bear Hollow, Bear Wallow Creek, Bear Spring). Черные медведи также встречаются и в некоторых частях Аляски (189 ед.): гидронимы Bear Bay, Bear Harbor, спелеонимы Bear Cape, Bear Glacier Point, инсулонимы Bear Island, Bear Rock $u$ m.д., и в небольших районах на юго-западе и юго-востоке Оклахомы, где насчитывается 313 зоотопонимических единиц, преимущественно гидронимы: Black Bear Spring, Bear Fall, Black Bear Creek, Bear Dam, Bear Creek Cove.

Медведь гризли и бурый медведь относятся к одному виду медведей. Несмотря на то, что большая часть их ареала обитания - прибрежная территория Аляски и Северо-Западная Канада, они также встречаются в небольших районах других штатов, в том числе в Северо-Западной части Монтаны, Национальном парке Йеллоустоун, северной части Юты (175 ед.): Bear Fork, Bear Hole Hollow, Bear River Valley, Bear Trap Canyon и небольшой части северо-запада Вашингтона, где насчитывается 169 зоотопонимических наименований: Grizzly Bear Trail, Bear Swamp, Bear River, Bear Paw Ridge, Bear Camp и т.д. Самые крупные, белые медведи, встречаются только в самых северных районах Аляски и Канады [5] Polar Bear Peak, Polar Bear Creek.

Наибольшее количество топонимов с зооэлементом "bear" насчитывается в штате Калифорния (657 ед.), хотя в настоящее время медведи в этом штате почти не водятся. Это связано с тем, что калифорнийский бурый медведь или калифорнийский гризли, обитавший на территории штата и игравший существенную роль в экосистеме региона, с прибытием европейцев был постепенно истреблен, и к 1922 году полностью вымер. Этот подвид бурого медведя изображён на флаге Калифорнии и является символом 
штата. Иногда его называли также калифорнийским золотым (золотистым) медведем. Таким образом, зоотопонимы могут отражать историческую составляющую местности.

Встречаются так же примеры вторичной номинации например, штат Арканзас называют “bear state”. «Вторичная номинация представляет собой использование уже имеющихся в языке номинативных средств в новой для них функции наречения» [Уразметова 2017: 9]. В этом штате насчитывается 148 географических названий с зоокомпонентом “bear". Такое название штата связано с историей данной территории: колонисты, оставшиеся жить в Посте Арканзас, отправляли на рынок Нового Орлеана медвежий жир.

На территории США существует «Долина гризли» - так называют Национальный парк Йеллоустоун, находящийся на территории 3 штатов: Вайоминг, Монтана, Айдахо. Распространенность зоотопонимов с элементом bear в каждом из штатов - 188, 315 и 274 единиц соответственно. Примеры зоотопонимов: названия долин Bear Pocket, Little Bear Canyon, Bear Coulee, Little Bear Gulch оронимы Bear Head Mountain, Bears Ears Mountain, Bears Tooth, She-Bear Mountain, Bear Skull Mountain, Bears Nest, Curly Bear Mountain, Black Bear Hump. Более того, символом штата Монтана является обычный гризли. Штат Орегон часто называют страной черных медведей, что подтверждает количество зоотопонимов с элементом bear - 313 наименований (Bear Bluff, Bear Butte, Bear Claw Canyon, Bear Hunt Gulch, Bear Meadow, Bear Mine, Bear Pass, Bear Riffle). B Пенсильвании, где насчитывается 232 данных зоотопонима (Black Bear Hill, Black Bear Run, Black Bear Swamp, Black Bear Trail, Bear Gap, Bear Den Hollow, Bear Knob, Bear Loop Run, Bear Lick), черные медведи обитают вблизи жилищ людей, поэтому нередки нападения этого зверя на человека.

Однако в штате Гавайи не зафиксировано ни одного географического объекта с данным зоокомпонентом, так как там медведи не встречаются.

Таким образом, на примере исследования зооэлемента “bear” в географических названиях США можно сделать вывод, что распространённость данных зоотопонимов зависит от ареала обитания этого зверя. Интересен тот факт, что в основном зоокомпонент bear имеют названия водоемов и поднятых форм 
рельефа, а именно гор, хребтов, вершин, холмов (оронимы). Распространены также топонимы с названиями частей тела медведя, например Bear Skull, Bear Paw, Bear Knob, Bear Claw, Bear Hump, Bears Tooth, Bears Ears, Bear Head и т.д. Можно сделать вывод, что процесс (языковой) номинации топонимической системы США напрямую зависит от мышления человека, его языковой картины мира и окружающей его среды.

1. Болдырев Н.Н. Типология концептов и языковая интерпретация / Н. Н. Болдырев // Новая Россия: традиции и инновации в языке и науке о языке: материалы докладов и сообщений Международной научной конференции, посвященной юбилею Заслуженного деятеля науки РФ, доктора филологических наук, профессора Л. Г. Бабенко, 28-30 сент. 2016 г., Екатеринбург, Россия. - Москва; Екатеринбург: Кабинетный ученый, 2016. - С. 16-25.

2. Болдырев Н.Н. Когнитивные исследования языка. Вып. XXXVII: Интегративные процессы в когнитивной лингвистике: материалы Международного конгресса по когнитивной лингвистике. 16-18 мая 2019 г. / отв. ред. вып. Т.В. Романова. - Нижний Новгород: Издательство ДЕКОМ, 2019. - $1144 \mathrm{c}$.

3. Серебренников Б.А. Как происходит отражение картины мира в языке // Роль человеческого фактора в языке: Язык и картина мира. М.: Наука, 1988. - С. 87-107.

4. Уразметова А.В. Топонимическая система США: первичная и вторичная номинация: монография / А.В. Уразметова. Уфа, 2017. - 90 c.

5. URL: Where Do Bears Live In North America? https://geology.com/stories/13/bear-areas/

(c) Нафикова Р.К., 2021 г. 